\title{
Uncertainties and nonstationarity in streamflow projections under climate change scenarios and the ensuing adaptation strategies in Subarnarekha river basin, India
}

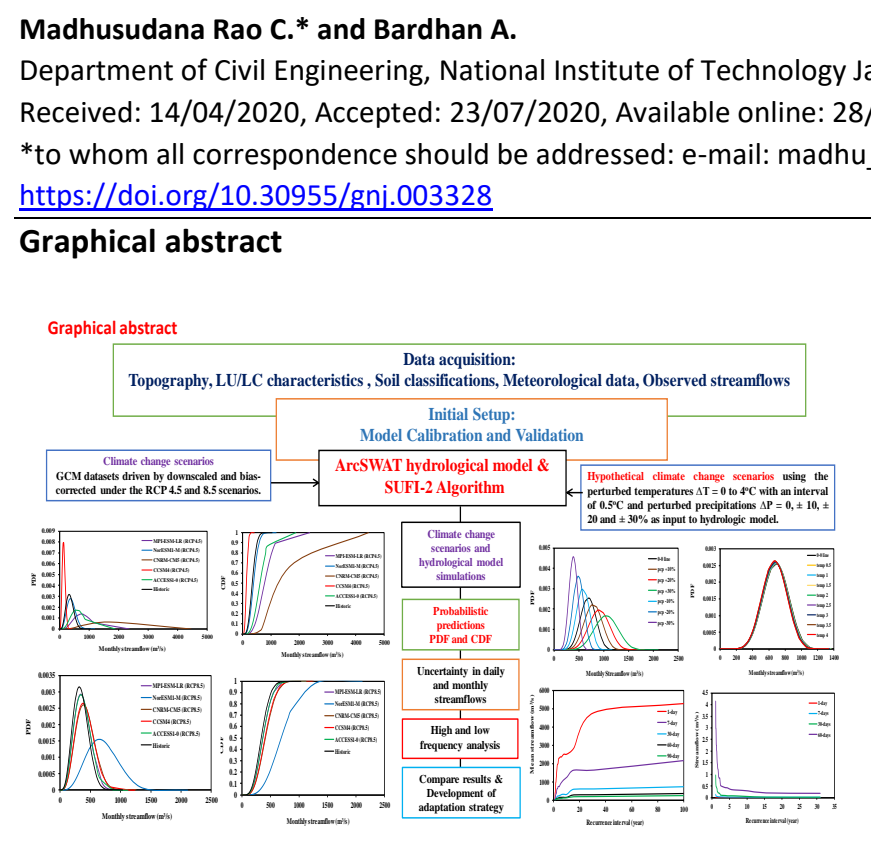

Abstract

The present study analyses the various uncertainties and nonstationarity in the streamflow projections of Subarnarekha river basin in Eastern India using two widely used hydrological climate models: 1) general circulation model (GCM), and 2) forcing climate change scenarios. These two climate models are used to force the ArcSWAT model. Subsequently this model is calibrated using SUFI-2 optimization technique. The downscaled and bias-corrected data from an ensemble of 10 climate projections with representative concentration pathways (RCP) 4.5 and 8.5 scenarios (five each) were used in first model, whereas in second model a total of 63 (7 perturbed precipitations and 9 perturbed temperatures) combinations of hypothetical climate change scenarios were used. The results show very good correlation during monthly calibration time steps and relatively good agreement between the observed and simulated streamflows in daily calibration time steps. The uncertainties are expressed in probabilistic terms using probability density function (PDF) and cumulative distribution function (CDF) as they provide significant information for decision process in climate change adaptation in the river basin. The uncertainties associated with climate models, return periods and streamflow extremes are also analysed in the present work. The RCP 8.5 scenarios seem more appropriate than RCP 4.5 scenarios in quantifying the uncertainties under nonstationarity assumptions. The mean values of water balance components and their percentage variation for both historic and future periods reveal that the water balance components get affected significantly due to climate change in a future period. Consequently, the streamflows are likely to decline in the river basin. The present study also highlights the comprehensive approaches that are being planned to facilitate adaptation to climate change as well as those that are specific to the water resources management in the study region. The findings in this work are useful for overall well-being of people in the study area.

Keywords: Uncertainty, nonstationary, forcing climate change, GCM, ArcSWAT, SUFI-2, streamflows.

\section{Introduction}

According to the $4^{\text {th }}$ climate report from the Intergovernmental Panel on Climate Change (IPCC, 2007), there is at least $90 \%$ certainty that human activities are causing global warming. The warming of global climate is unequivocal and is evidenced by numerous observations of increasing air and ocean temperatures, melting of snow and ice, and rising global average sea level (Joseph, 2009). To deal with the future global warming, reliable estimates of regional patterns and amplitudes of climate changes are required. The reliable estimates can be made through the widely used climate models e.g., general circulation models (GCM) and forcing climate change scenarios that account for a variety of processes and interactions in the Earth's climate system. The processes viz., downscaling techniques, climate projections and techniques for hydrological simulations with their associated discrepancies introduce uncertainty in impact analysis (Mujumdar and Ghosh, 2008; Kure et al., 2013).

In the changing climate context, it is presumed that uncertainties arise from (i) approximations and omissions required when representing the real-world process in climate models (Paeth et al., 2013), (ii) multi scale interval 
variability and inaccurate initial conditions (Palmer and Anderson, 1994), and (iii) observational data that are subject to gaps or inhomogeneity and measurement errors (Brohan et al., 2006; Hunt, 2011).

This implies that the climate change impact assessment research and decision making using climate models in adaptation and mitigation processes have to cope with these uncertainties. The climate models still have significant deficiencies and differ in terms of their anticipated climate change, particularly at a regional scale (Paeth et al., 2010; 2013). Therefore, the claim for exact predictions on one side and uncertain model results on the other side is typical for scientific issues dealing with complex systems like river basins.

In recent research, an emerging feature of all aspects of climate change scenarios is the growing use of probabilistic terms such as probability density function (PDF) and cumulative distribution function (CDF) which can provide detailed quantitative descriptions of uncertainties of climate change scenarios. Many studies (e.g., Giorgi and Mearns, 2003; Wilby and Harris, 2006; Kay et al., 2009; Prudhomme and Davies, 2009; Paeth et al., 2013; Gillingham et al., 2015; Das and Umamahesh, 2017; Sung et al., 2018; Mackay et al., 2019) have carried out the quantification of uncertainties in climate change impact assessment using meteorological parameters and expressed in probabilistic terms. Sometimes, an ensemble approach is also applied to deal with the uncertainty in climate scenarios because a specific scenario cannot represent all future climate conditions (Sung et al., 2018). But, it is still questionable that, which scenarios needed to include in the climate change impact assessment procedure for capturing future climate variability.

Most studies have selected appropriate scenarios based on the performance in reproducing historical climate. However, it has the limitation that performance during a historical period cannot guarantee consistent performance during a future period (Lee et al., 2016). In this context, it is suggested to use as many climate scenarios as possible in climate change assessment (IPCC, 2014). In other words, employing multiple scenarios in climate change impact assessment may take the uncertainties into account.

In river basin studies, it is certain that there remains a considerable uncertainty in future predictions of streamflows because of the forcing climate change scenarios (Ramadan et al., 2013). Generally, forcing climate change scenarios represent the perturbed precipitations $(\Delta \mathrm{P}=0, \pm 10$ to $\pm 30 \%)$ and perturbed temperatures $(\Delta \mathrm{T}=0$ to $4^{\circ} \mathrm{C}$ ) adding the prescribed changes to the baseline or 0 -line (observational) dataset i.e., precipitations and temperatures. The use of these climate change scenarios involves a vast array of uncertainties that complicate the correct assessment of water resources potential in river basins.

Further, in climate change scenarios the risk and streamflow assessment is generally carried out through return periods under nonstationarity assumptions, as these assumptions enable to introduce time-varying concepts for better assessment (Cooley, 2013; Mondal and Mujumdar, 2016). The analysis of nonstationary approximations of the return levels under lower return periods may be more beneficial to design low-capacity hydraulic structures (Das and Umamahesh, 2017). The low flows are also significant parameters in hydrology (Kiely, 2007). Traditionally, hydrologists were preoccupied with flood alleviation and so analysis for high flows is more commonplace than that of low flow analysis. However, analysis of low flows is of significant interest, particularly in relation to water abstractions for water supply and hydroelectricity.

Evaluation of changing climate related impact on future streamflows in a river basin is normally handled by simulating the hydrologic behaviour of the basin under projected climate conditions (Jana et al., 2018). This in turn requires developing a hydrological model i.e., depicting the hydrological response for the basin under consideration. In order to know the hydrological behaviour of river basins for the effective planning and management of soil and water resources, the applications of Soil and Water Assessment Tool (ArcSWAT) (Arnold et al., 1998) have been increased invariably across the world (Gassman et al., 2007; Shawul et al., 2013; Narsimlu et al., 2013; 2015). ArcSWAT model could be effectively used for daily and monthly streamflow predictions and also for estimating water budgets at river basin-scales (Madhusudana Rao et al., 2020).

In addition, some researchers (e.g., Xu et al., 2003; Huang et al., 2006; Das and Umamahesh, 2017) have used a 3layer variable infiltration capacity (VIC-3L) model for hydrological modelling to forecast the future streamflows of river basins. However, running the VIC model may seem to be a formidable task (https://vic.readthedocs.io/ en/master/Documentation/UserGuide/) as it involves complex process to follow.

Alternatively, it is felt that the ArcSWAT model may be applied in place of VIC model. The inputs from the downscaled GCM and bias-corrected datasets, and forcing climate change scenarios are used separately to force the ArcSWAT model and subsequently this model can be calibrated using SUFI-2 optimization technique. Upon satisfactory performance, the calibrated model is used for prediction of streamflows in the river basin under the climate change scenarios.

In this context, in the present study an effort is made to verify the use of downscaled GCM and bias-corrected datasets, and also forcing climate change scenarios as inputs in the ArcSWAT model for prediction of streamflows of Subarnarekha river basin in Eastern India under climate change scenarios as this river basin is frequently affected by climate change in recent years.

In order to provide detailed quantitative descriptions of uncertainties of climate change scenarios in the Subarnarekha river basin the probability density function (PDF) and cumulative distribution function (CDF) are planned to assess. Further, in this river basin the estimation of low flow duration frequency curves for recurrence interval in years considering the lower return periods for uncertainty analysis are more 
susceptible to climate change and most likely to vary in terms of magnitudes i.e., return level. Similarly, to carry the high flow analysis it is essential to know the extreme events occurring in the Subarnarekha river basin.

In previous studies, (e.g., Dessai et al., 2005; Wilks, 2006; Paeth et al., 2013; Vanem, 2015; Das and Umamahesh, 2017; Mandal and Simonovic, 2017; Mohammed et al., 2017; Jobst et al., 2018; Mackay et al., 2019;
Rai et al., 2019; Spafford et al., 2020) the uncertainties in precipitation, temperature and streamflows of river basins are expressed in probabilistic terms, typically using PDF and sometimes PDF and CDF both. But in most of the previous studies, the uncertainties in low flows and high flows are not expressed in probabilistic terms such as PDF and CDF, even though they are very important for developing adaptation strategies in the river basins.

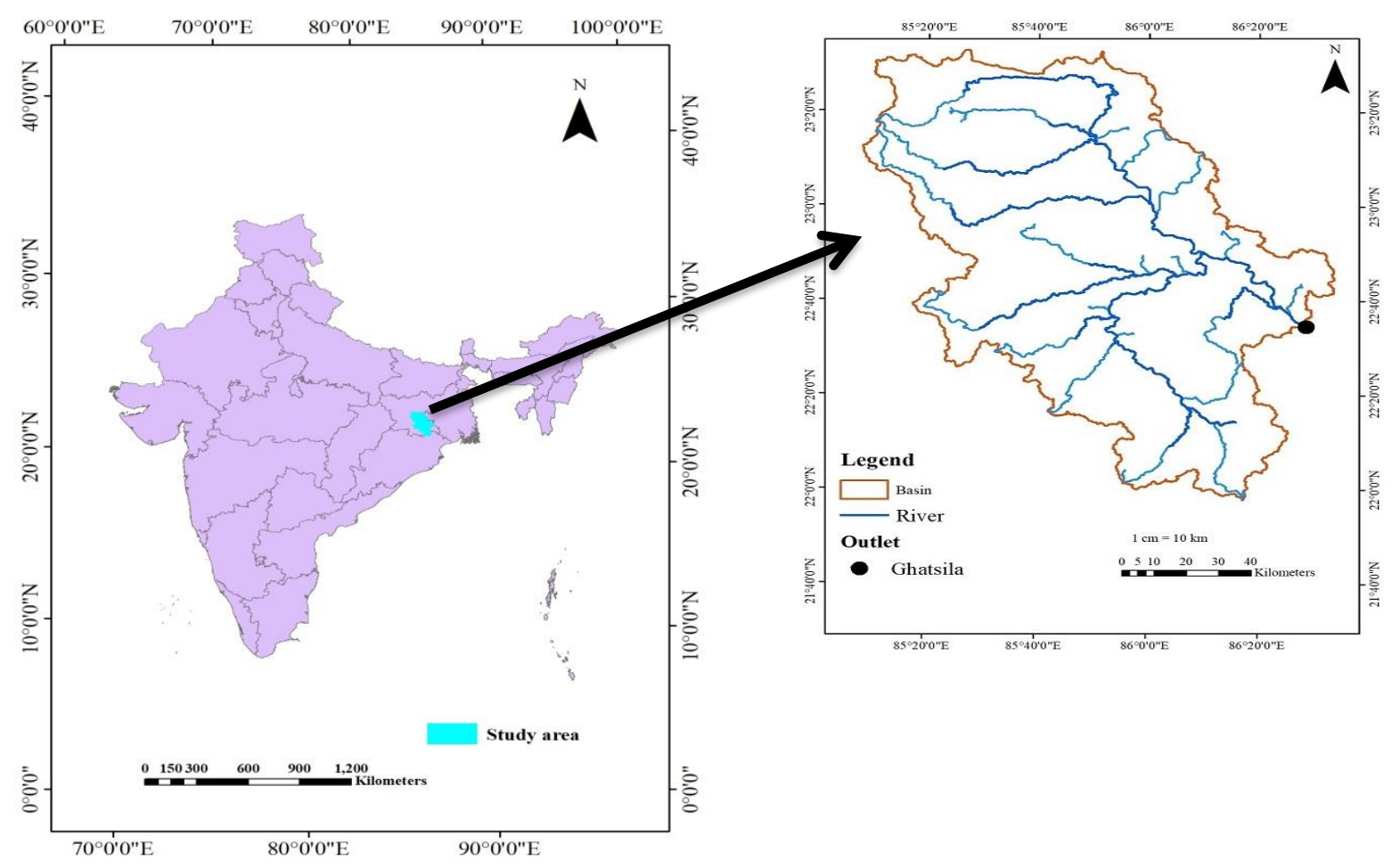

Figure 1. Location map of Subarnarekha river basin with Ghatsila gauging station.

This persisting research gap is filled as a novel attempt in the present study by expressing the uncertainties in low flows and high flows of Subarnarekha river basin in both PDF and CDF. No such work is seen in reviewed literature on this river basin. Though the Subarnarekha river basin is a major river basin in India, significant research work is not done on this river basin. Few research works (e.g., Jana, et al., 2015; Yaduvanshi, et al., 2017; Yaduvanshi, et al., 2019; Kumar and Joshi, 2019; Banerji and Mukhopadhyay, 2018) are available in literature, but they failed to explain the uncertainties in streamflow projections under the climate change scenarios, even though they are very important for water management and agricultural practices in the river basin. This research gap motivated us to select this river basin for present study.

The assessment of uncertainties in low flows and high flow events play a significant role in identifying the drought (low flow) and flood (high flow) effected regions in this river basin to prepare the ensuing adaptation strategies. Therefore, it is proposed to develop PDF and CDF for low flows and high flows along with the monthly and daily streamflows in the present study under climate change scenarios. In order to know the climate change impact on the future streaflows in the Subarnarekha river basin, the mean water balance components for historic and future periods are assessed for the first time for this basin in the present study.

The water sector and its resources in the Subarnarekha river basin are facing threat due to industrial and uneven urban growth, both temporally and spatially. Hence the challenge of climate change calls for suitable comprehensible policy response that can help to reduce its vulnerability and build resilience of the water sector of Subarnarekha river basin (Government of Jharkhand (2013). The overall water sector vision, adaptation policy framework and assurance will be to improve water management practices through several strategies and initiatives in the study area to minimize the impacts of climate change and for the overall comfort of people in the study area.

Further, assessment of uncertainties in future streamflows of Subarnarekha river basin using nonstationarity assumptions under climate changing conditions will help the water resources professionals to develop water 
management strategies and climate change adaptations in the river basin, as it is significantly affected by climate change in recent years and it urgently requires reliable hydrological estimates.

Table 1. Show the spatial data description and their sources

\begin{tabular}{|c|c|c|c|}
\hline Sl. No. & Spatial data & Description/resolution & Source \\
\hline 1. & Digital Elevation Model & $\begin{array}{c}30 \mathrm{~m} \times 30 \mathrm{~m} \text { grid resolution } \\
\text { DEM to represent the } \\
\text { topography }\end{array}$ & $\begin{array}{l}\text { Shuttle Radar Topography } \\
\text { Mission (SRTM) of USGS }\end{array}$ \\
\hline 2. & Land use and land cover & $\begin{array}{c}1 \mathrm{~km} \times 1 \mathrm{~km} \text { grid resolution } \\
\mathrm{LU} / \mathrm{LC} \text { map to represent the } \\
\text { crops and urban specific digital } \\
\text { layers }\end{array}$ & $\begin{array}{c}\text { Nation Remote Sensing } \\
\text { Centre, India/Water Resources } \\
\text { information System } \\
\text { (http://www.india- } \\
\text { wris.nrsc.gov.in) and Texas A \& } \\
\text { M University } \\
\text { (http://swat.tamu.edu/) }\end{array}$ \\
\hline 3. & Soil & $\begin{array}{c}1 \mathrm{~km} \times 1 \mathrm{~km} \text { grid resolution soil } \\
\text { map to demonstrate the soil } \\
\text { layer }\end{array}$ & $\begin{array}{l}\text { Food and Agriculture } \\
\text { Organization (FAO) }\end{array}$ \\
\hline 4. & Hydrological data & $\begin{array}{c}\text { Gauged daily discharge data at } \\
\text { Ghatsila gauging station of } \\
\text { Subarnarekha river (Year, } 2000 \\
\text { to 2013) }\end{array}$ & $\begin{array}{l}\text { Central Water Commission } \\
\text { (CWC), New Delhi, India }\end{array}$ \\
\hline 5. & $\begin{array}{l}\text { Weather inputs (for model } \\
\text { simulation) }\end{array}$ & $\begin{array}{c}0.25^{\circ} \times 0.25^{\circ} \text { grid resolution } \\
\text { daily precipitation data and } \\
0.5^{\circ} \times 0.5^{\circ} \text { grid resolution data } \\
\text { of other weather inputs }\end{array}$ & $\begin{array}{c}\text { Indian Meteorological } \\
\text { Department (IMD), Pune, India }\end{array}$ \\
\hline 6. & Climate change data & $\begin{array}{l}0.5^{\circ} \times 0.5^{\circ} \text { grid resolution } \\
\text { precipitation and temperature } \\
\text { (maximum and minimum) data }\end{array}$ & $\begin{array}{l}\text { CORDEX-South Asia data set } \\
\text { from IITM }\end{array}$ \\
\hline
\end{tabular}

\section{Study area}

The present study is carried out on Subarnarekha river basin, the smallest river basin of the 14 major river basins in India. This river basin is situated between latitudes $21^{\circ}$ $33^{\prime}$ to $23^{\circ} 32^{\prime} \mathrm{N}$ and longitudes $85^{\circ} 09^{\prime}$ to $87^{\circ} 27^{\prime} \mathrm{E}$. The location map of the study area is given in Figure 1 . The total catchment area of the river basin is $14140 \mathrm{~km}^{2}$ with high topographical variations ranging from $49 \mathrm{~m}$ to $1049 \mathrm{~m}$ above mean sea level. The Subarnarekha river stretches to a length of $395 \mathrm{~km}$ through Jharkhand, West Bengal and Orissa states of Eastern India. The Ghatsila, a gauging station of the Subarnarekha river basin situated in the Jharkhand state levers all the upstream runoff in the Jharkhand state. The tail river reach which is located down below the Ghatsila gauging station is passing through West Bengal and Orissa states and is not considered in the present work.

The climate is tropical with hot summer and mild winters in the study area. The annual average maximum and minimum temperatures vary from $32.40{ }^{\circ} \mathrm{C}$ to $18.00^{\circ} \mathrm{C}$ and the mean monthly temperatures vary from $40.5^{\circ} \mathrm{C}$ in the month of May to $9.00{ }^{\circ} \mathrm{C}$ in the month of December. The Subarnarekha river is mostly a rain fed peninsular river with the wet months being June to September and during dry period the river flow is almost nil. This river basin is influenced by the South-West monsoon (June to October) and the annual average precipitation is about $1800 \mathrm{~mm}$.
The comprehensive summaries from the recent studies conducted on Subarnarekha river basin (e.g., Jana et al., 2015; Yaduvanshi, et al., 2017 \& 2019; Kumar and Joshi, 2019) demonstrated that this river basin is found to be prone to climate change. There is decrease in rainfall and ensuing decreased streamflows of the river basin mostly in June to September period for almost half of the future years. The water balance components are affected due to climate change impact. The surface runoff shows an average annual decrease by $18.4 \%$. There is an increasing trend of actual evapotranspiration in the recent 20 years period, which is an alarming situation for the agricultural in the study region. Increase of annual 24-h maximum rainfall and associated increase in the annual flood maxima with time of occurrence of peak rainfall and peak flow shifting from monsoon period to the month of May were also apparent in the study area.

The inferences from these studies show that, this river basin is on the front line of climate change in recent years, and is affected by uncertain streamflows, frequent droughts and water crises for agriculture, drinking water and other purposes that necessitate the reliable hydrological estimates for the study region.

\section{Methods and materials}

Two hydrological climate models: 1) general circulation model (GCM), and 2) forcing climate change scenarios are used to analyse various uncertainties and nonstationarity in the streamflow projections of Subarnarekha river basin. 
These two climate models are later used to force the ArcSWAT hydrological model simulation. In the first model, downscaled and bias-corrected data from an ensemble of 10 climate projections with representative concentration pathways (RCP) 4.5 and 8.5 scenarios (five each) were used as input. Whereas, in the second model, a total of 63 (9 perturbed temperatures and 7 precipitations) anticipated hypothetical climate change scenarios such as combinations of temperature change $\Delta \mathrm{T}=0$ to $4^{\circ} \mathrm{C}$ with an interval of $0.5^{\circ} \mathrm{C}$ and precipitation change $\Delta \mathrm{P}=0, \pm 10, \pm 20$ and $\pm 30 \%$ were considered as input. The procedure as used by Ramadan et al., 2013; Madhusudana Rao et al., 2020 is followed herein to develop these forcing climate changing scenarios.

The major inputs, viz. digital elevation model (DEM) to represent the topography, soil maps to show the soil layers in the study region, land use/land cover (LU/LC) characteristics and hydro-meteorological data like daily rainfall in $\mathrm{mm}$, minimum and maximum daily temperature in ${ }^{\circ} \mathrm{C}$, relative humidity, solar radiation and wind speed are used for the initial ArcSWAT model setup. The grid resolutions and the sources of major inputs i.e., spatial data are summarized in Table 1. The observed streamflow data for a period of 14 years (2000 to 2013) pertaining to the Ghatsila gauging station of the Subarnarekha river basin is obtained from central water commission (CWC), New Delhi, India.

In this study, the regional climate model namely Conformal-Cubic Atmospheric Model (CCAM) is based on Coupled Model Intercomparison Phase 5 (CMIP5) used for RCP4.5 and RCP8.5 scenarios. Five (ACCESS1-0, CCSM4, CNRM-CM5, MPI-ESM-LR, and NorESM1-M) historical and future simulated high-resolution GCM datasets for the RCP 4.5 and 8.5 scenarios were collected from high resolution coordinated regional climate downscaling experiment (CORDEX)-South Asia of Indian institute of tropical meteorology, Pune (IITM, 2016). The GCM outputs were downscaled through CORDEX. These downscaled GCM datasets are bias-corrected through R-software.

The bias-correction approach corrects the projected raw (uncorrected) daily GCM output using the differences in the statistics values such as mean, standard deviation and variance between GCM and observations of meteorological parameters (precipitation, maximum and minimum temperatures) in a reference period. Here, the period considered for the bias-correction is 1970 - 2005 for precipitation and maximum and minimum temperatures. The bias-correction includes model simulations during calibration to ensure their statistics values are similar to those of the corresponding observed values. The linear and non-linear correction techniques are widely practiced to correct the existing biases in climate datasets (Leander and Buishand, 2007).

In the present study, the procedure as suggested by Leander and Buishand (2007) is adopted and thus the nonlinear correction technique for precipitation and linear correction technique for maximum and minimum temperatures are applied to correct the existing biases in climate datasets. Typically, in the meteorological parameters the precipitation variability is high and the temperature variability is consistent. On the basis of these characteristics, the use of non-linear correction procedure for precipitation and linear correction procedure for temperatures is appropriate (Shabalova et al., 2003). Table 2 demonstrates the obtained statistics values of observed, uncorrected (raw) and bias-corrected meteorological parameters. This bias-corrected data is used in the ArcSWAT hydrological model as an input.

Table 2. The statistics values of observed, uncorrected and bias-corrected meteorological parameters.

\begin{tabular}{ccccccc}
\hline Parameters & \multicolumn{2}{c}{ Precipitation } & \multicolumn{2}{c}{ Maximum Temperature } & \multicolumn{2}{c}{ Minimum Temperature } \\
\hline \multirow{3}{*}{ Mean } & Observed & 8.04 & Observed & 32.43 & Observed & 19.95 \\
\cline { 2 - 7 } & Uncorrected & 3.75 & Uncorrected & 32.18 & Uncorrected & 20.03 \\
\cline { 2 - 7 } & Corrected & 8.20 & Corrected & 32.55 & Corrected & 19.71 \\
\hline \multirow{3}{*}{ Standard Deviation } & Observed & 10.76 & Observed & 6.42 & Observed & 5.87 \\
\cline { 2 - 7 } & Uncorrected & 8.08 & Uncorrected & 6.47 & Uncorrected & 5.75 \\
\cline { 2 - 7 } & Corrected & 10.95 & Corrected & 6.40 & Corrected & 6.03 \\
\hline \multirow{3}{*}{ Coefficient of Variation } & Observed & 1.34 & Observed & 0.20 & Observed & 0.29 \\
\cline { 2 - 7 } & Uncorrected & 2.15 & Uncorrected & 0.20 & Uncorrected & 0.29 \\
\cline { 2 - 7 } & Corrected & 1.33 & Corrected & 0.20 & Corrected & 0.31 \\
\hline
\end{tabular}

In ArcSWAT, the Subarnarekha river basin is delineated into 21 sub-basins, which are then further subdivided in to 251 HRUs (hydrological response units) that acceptably characterize the heterogeneity in this river basin. Threshold refinements for HRU definition are not employed in the present study. This ArcSWAT model is used for simulation of hydrological data on daily and monthly time scales for the observed data period from the year 2000 to 2013 (14 years). The starting two years data during 2000 to 2001 are used as warming periods for initial model set-up. The data during the years 2002 to 2009 ( 8 years), and 2010 to 2013 (4 years) are analysed for streamflow calibration and validation, respectively. The quantification of the uncertainty in ArcSWAT model output was assessed using a sequential uncertainty fitting algorithm (SUFI-2).

Using historic period 1976 to 2005 dataset in the calibrated ArcSWAT model, the future streamflow predictions are obtained for near future period 2014 to 2040 under the RCP 4.5 and 8.5 scenarios. Here, the cut off year 2013 is the end of available data. Therefore, the simulation is planned to end for the year 2013. Subsequently, the starting year of the near future period 
begins from the year 2014. This type of assumption is well practiced in many earlier research works (e.g., Mishra and Lilhare, 2016; Mudbhatkal

Table 3. Show the streamflows calibration and validation results on daily and monthly basis

\begin{tabular}{cccccc}
\hline SI. No. & Indices & \multicolumn{2}{c}{ Daily time step } & \multicolumn{2}{c}{ Monthly time step } \\
\hline & & Calibration & Validation & Calibration & Validation \\
\hline 1 & $\mathrm{R}^{2}$ & 0.84 & 0.76 & 0.98 & 0.94 \\
\hline 3 & $\mathrm{NSE}$ & 0.84 & 0.76 & 0.97 & 0.94 \\
\hline 4 & $\mathrm{PBIS}$ & 1.10 & 11.30 & 7.30 & 0.17 \\
\hline 5 & $\mathrm{RSR}$ & 0.40 & 0.49 & 0.25 \\
\hline 6 & $\mathrm{p}$-factor & 0.58 & 0.42 & 0.85 & 0.44 \\
\hline
\end{tabular}
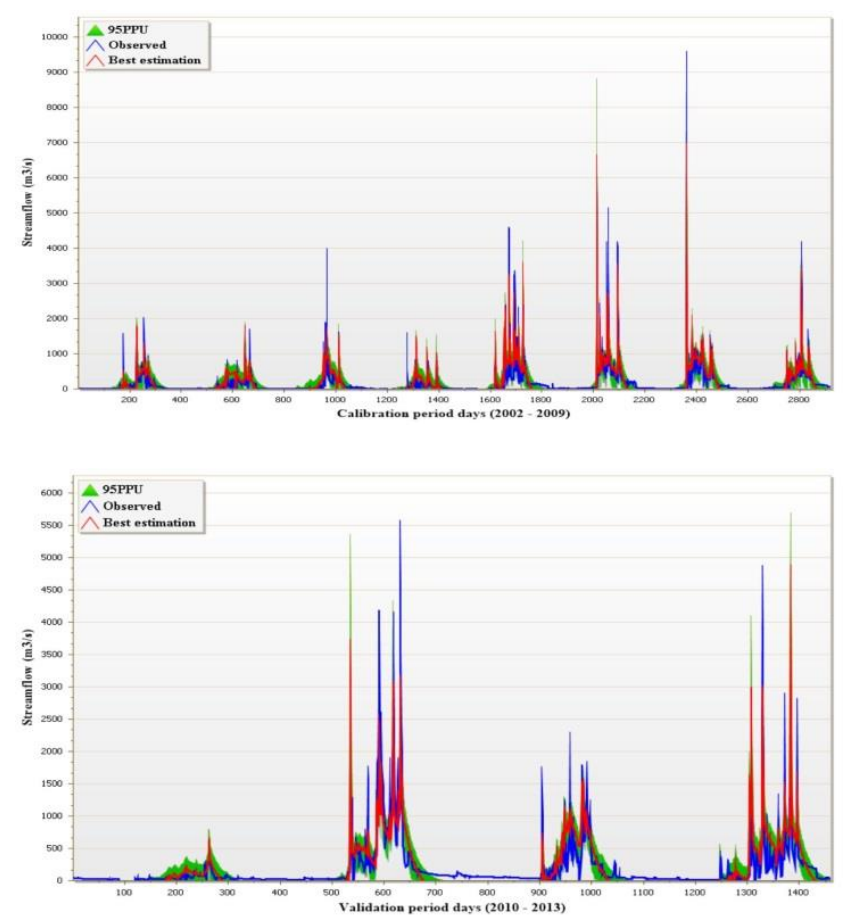

Figure 2(a). Daily streamflows during calibration and validation periods.

In the present study, various uncertainties and nonstationarity in the streamflow projections of Subarnarekha river basin are calculated using RCP 4.5 and 8.5. The uncertainties are expressed in probabilistic term using PDF and they can be estimated by representing the climate model results as random samples from climate change scenarios (IPCC, 2007). The PDF span various amplitudes of climate change in terms of probability space associated with uncertain climate change. The probabilistic predictions allow for quantification of uncertainty and they provide important information for decision process in climate change adaptation (Collins et al., 2006). Many studies (e.g., Wilks, 2006; Hingray et al., 2007; Paeth et al., 2013; Das and Umamahesh, 2017; Sung et al., 2018) have concluded that the probabilistic assessments resulting from the comparison between the PDF of current and future under regional changing climate scenarios are useful tools to study climate change. In addition, the other probability term CDF can also be worked out for calculation of occurrence of extreme events of floods in the river basin studies.

Further, the quantification of risk and reliability is made on stationary and nonstationarity assumptions. In stationary assumptions the moments and parameters are considered to be time independent (Read and Vogel, 2015), whereas, in the case of nonstationarity assumptions they are considered to be time-varying (IPCC, 2007; Milly et al., 2008; Cooley, 2013). The nonstationarity is investigated by calculating the mean, standard deviation (SD), Coefficient of Variation (CV) and Covariance (CoV) values obtained for different climate change scenarios, such as historical and future periods using RCP 4.5 and RCP 8.5. These nonstationarity assumptions have become important to the researchers for better planning and risk management under climate change scenarios (Das and Umamahesh, 2017).

Furthermore, in order to know the maximum flows in the river basin, the high flows against their recurrence periods 7-day, 30-day, and 60-day values are estimated using Gumbels extreme value distribution approach under nonstationarity assumptions. The low flow characteristics against their recurrence periods 7-day, 30-day, and 60-day values are also estimated under nonstationarity assumptions for drought determination and aquatic ecosystems in Subarnarekha river basin.

\subsection{Performance evaluation criteria}

In the present study, the ArcSWAT model performance during calibration and validation is evaluated with reference to six selected statistical indicators, namely coefficient of determination $\left(R^{2}\right)$, Nash-Sutcliff Efficiency (NSE), percentage bias (PBIAS), and RMSE (Root Mean Square Error)-observations standard deviation ratio (RSR), p-factor (observations bracketed by the prediction uncertainty), and $r$-factor (achievement of small uncertainty band).

The goodness of fit can be quantified by the $\mathrm{R}^{2}$, NSE (Nash and Sutcliffe, 1970) and PBIAS (Yapo et al., 1996) between the observed and the simulated data. The closer the value of $R^{2}$ to 1 , the simulated and observed values are very close, which means that the performance of the model is 
above satisfactory level. NSE indicates 1:1 line fit between observed and simulated data (Narsimlu et al., 2013). NSE values ranges between $-\infty$ to 1 (perfect fit), with optimal value of 1 (ASCE, 1993).

The PBIAS determines the tendency of simulated flows to be larger or smaller than their observed counterparts (Fiseha et al., 2012). The optimum value is zero, positive value indicates a tendency to underestimation and negative value indicates a tendency to overestimation (Gupta et al., 1999; Verma and Jha, 2015).
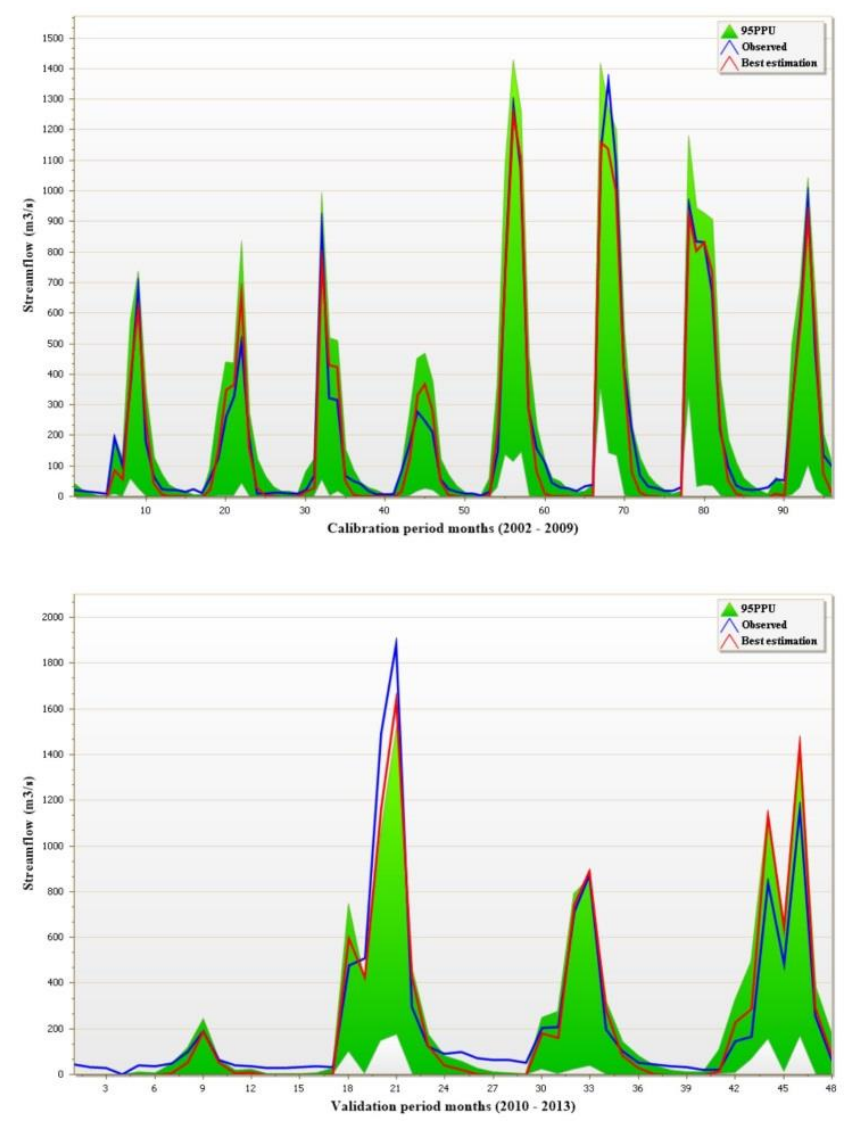

Figure 2(b). Monthly streamflows during calibration and validation periods.

The RSR is one of the commonly used error index statistics (Singh et al., 2004; Moriasi et al., 2007). It is calculated as the ratio of the RMSE and standard deviation of the observed data. The RSR varies from the value of 0 , indicating zero RMSE or residual variation (perfect model simulation) to a large positive value. The lower the RSR the better is the model fit (Moriasi et al., 2007).

The $p$-factor signifies the percentage of observed data bracketed by $95 \%$ prediction uncertainty (95PPU) band and the r-factor denotes the thickness of 95PPU band. The value of $p$-factor very close to 1 and the value of $r$-factor nearly to zero signify excellent model performance with higher probability and lower uncertainty (Abbaspour et al., 2007; 2011; Uniyal et al., 2015).

The formulae used for calculation of $R^{2}, N S E, P B I A S$, and RSR are given in Equations (1), (2), and (3), respectively as follows:

$$
\begin{gathered}
R^{2}=\frac{\left[\sum_{i}\left(Q_{0, i}-\bar{Q}_{0}\right)\left(Q_{s, i}-\bar{Q}_{s}\right)\right]^{2}}{\sum_{i}\left(Q_{0, i}-\bar{Q}_{0}\right)^{2} \sum_{i}\left(Q_{s, i}-\bar{Q}_{s}\right)^{2}} \\
N S E=1-\frac{\sum_{i}\left(Q_{0}-Q_{s}\right)_{i}^{2}}{\sum_{i}\left(Q_{0, i}-\bar{Q}_{0}\right)^{2}} \\
\text { PBIAS }=100 \times \frac{\sum_{i=1}^{n}\left(Q_{0}-Q_{s}\right)_{i}}{\sum_{i=1}^{n} Q_{0, i}} \\
R S R=\sqrt{\frac{\sum_{i=1}^{n}\left(Q_{0}-Q_{s}\right)_{i}^{2}}{\sum_{i=1}^{n}\left(Q_{0, i}-\overline{Q_{0}}\right)_{i}^{2}}}
\end{gathered}
$$

where $\mathrm{Q}$ is a variable (i.e. discharge), $\bar{Q}_{o}$ and $\bar{Q}_{s}$ denote the average values of $Q$ and suffixes " $O$ " and " $s$ " stand for observed and simulated data. Here, " $\mathrm{i}$ " stands for $\mathrm{i}^{\text {th }}$ observed or simulated data.

\section{Results and discussion}

The values of statistical indicators, viz. $\mathrm{R}^{2}$, NSE, PBIAS, RSR, $p$-factor and r-factor of observed and simulated streamflows at daily and monthly time steps for ArcSWAT model calibration and validation periods are given in Table 3. It can be seen from Table 3 that correlation during monthly calibration time steps is very good, whereas daily calibration exhibits relatively good agreement between the observed and simulated flows. During the calibration period, NSE values for daily and monthly time steps are 0.84 and 0.97 , respectively, whereas in the validation periods they are 0.76 and 0.94 , respectively.

It indicates that the simulated streamflows are in very good agreement with observed streamflows during both calibration and validation periods. Similarly, the low RSR value $(<0.49)$ indicates high accuracy in the simulated streamflows during calibration and validation periods at both time steps. The obtained PBIAS value indicates that the ArcSWAT model is underestimating during the calibration and validation periods at both time steps (Table 3 ), but its values are within the range specified for good performance rating (i.e., $\pm 10<$ PBIAS $< \pm 15$, criteria given by Moriasi et al., 2007) of the model.

Figures 2(a) and 2(b) show the daily and monthly streamflows, respectively, during calibration and validation periods with 95PPU, observed and best estimation. It can be seen from Figure 2(a) and 2(b) that the observed and simulated streamflows are not significantly different at the 95\% level of confidence (95PPU) for calibration and validation periods at both daily and monthly time steps. The results of monthly time step were better than those for the daily time step. Figure 3(a) and 3(b) show the most sensitive parameters ( $p$-value and $t$-stat value) recorded after the SUFI-2 sensitivity analysis was performed for daily and monthly calibration periods, respectively.

Table 4. Showing the 7-day nonstationarity test values calculated for historic and future periods using RCP 4.5 and RCP 8.5 scenarios. 


\begin{tabular}{ccccc}
\hline Scenarios & Mean & SD & CV & CoV \\
\hline Historic & 0.031387 & 0.030528 & 97.2628 & $6.22 \mathrm{E}-06$ \\
\hline CCSM4_rcp85_2014_2040 & 0.089361 & 0.148127 & 165.7624 & -0.0006 \\
\hline CNRM-CM5_rcp85_2014_2040 & 0.083762 & 0.089706 & 107.0965 & -0.00315 \\
\hline NorESM1-M_rcp85_2014_2040 & 0.067874 & 0.078206 & 115.2224 & $6.06 \mathrm{E}-05$ \\
\hline MPI-ESM-LR_rcp85_2014_2040 & 0.076929 & 0.111478 & 144.9115 & -0.00182 \\
\hline ACCESS1-0_rcp85_2014-2040 & 0.077843 & 0.100506 & 129.1136 & 0.001819 \\
\hline CCSM4_rcp45_2014_2040 & 0.002118 & 0.005037 & 237.8227 & $-5.2 \mathrm{E}-07$ \\
\hline CNRM-CM5_rcp45_2014_2040 & 0.047291 & 0.056411 & 119.2837 & 0.000362 \\
\hline NorESM1-M_rcp45_2014_2040 & 0.069903 & 0.094836 & 135.668 & -0.00077 \\
\hline MPI-ESM-LR_rcp45_2014_2040 & 0.083232 & 0.134977 & 162.1695 & 0.001003 \\
\hline ACCESS1-0_rcp45_2014-2040 & 0.052118 & 0.069506 & 133.363 & -0.00035 \\
\hline
\end{tabular}

Table 5. Showing the 30-day nonstationarity test values calculated for historic and future periods using the RCP 4.5 and RCP 8.5 scenarios.

\begin{tabular}{ccccc}
\hline Scenarios & Mean & SD & CV & CoV \\
\hline Historic & 0.252826 & 0.216525 & 85.64186 & -0.00032 \\
\hline CCSM4_rcp85_2014_2040 & 0.526865 & 0.740859 & 140.6163 & -0.01019 \\
\hline CNRM-CM5_rcp85_2014_2040 & 0.558273 & 0.637209 & 114.1393 & -0.15706 \\
\hline NorESM1-M_rcp85_2014_2040 & 0.556089 & 0.584582 & 105.1238 & 0.070079 \\
\hline MPI-ESM-LR_rcp85_2014_2040 & 0.734266 & 1.318185 & 179.5242 & -0.23674 \\
\hline ACCESS1-0_rcp85_2014-2040 & 0.556285 & 0.685174 & 123.1696 & 0.140419 \\
\hline CCSM4_rcp45_2014_2040 & 0.107882 & 0.369593 & 342.5909 & 0.003815 \\
\hline CNRM-CM5_rcp45_2014_2040 & 0.385814 & 0.492475 & 127.6457 & 0.046754 \\
\hline NorESM1-M_rcp45_2014_2040 & 0.475966 & 0.510737 & 107.3054 & -0.05462 \\
\hline MPI-ESM-LR_rcp45_2014_2040 & 0.599489 & 0.925985 & 154.4623 & 0.161264 \\
\hline ACCESS1-0_rcp45_2014-2040 & 0.359644 & 0.44706 & 124.3061 & -0.0137 \\
\hline
\end{tabular}

Table 6. Percentage variations in mean water balance components and streamflows for the historic total (1976 - 2013) and near (20142040) periods of Subarnarekha river basin.

\begin{tabular}{cccr}
\hline Water balance component & Historic total (1976-2013) period & Near (2014-2040) period & Percentage variation (\%) \\
\hline PRECIP & 938.07 & 863.67 & -7.93 \\
\hline SURQ & 237.98 & 178.07 & -25.17 \\
\hline LATQ & 11.79 & 8.87 & -24.81 \\
\hline GW_Q & 131.15 & 117.81 & -10.17 \\
\hline PERC & 163.23 & 148.08 & -9.28 \\
\hline SW & 95.58 & 90.53 & -5.29 \\
\hline ET & 526.67 & 529.93 & 0.62 \\
\hline WYLD & 388.95 & 312.07 & -19.77 \\
\hline Streamflows & 126.93 & 107.40 & -15.39 \\
\hline
\end{tabular}

The quantitative description of uncertainties and nonstationarity in the streamflows of Subarnarekha river basin for the historic and the future periods are analysed in probabilistic terms by developing PDF and CDF through two climate models (i) general circulation model (GCM) under the RCP 4.5 and 8.5 scenarios, and (ii) forcing climate change scenarios.

Here, it is appropriate to recollect some pertinent characteristics of PDF and CDF from the earlier studies for better understanding of the obtained results in the present work. The shift of central mean of PDF is a measure of climate change effect, while the width of the PDF is an indication of noise or error (Paeth et al., 2013). The overlapping probability (OLP) arises from a combination of both and indicates to what extent PDF of the past and future climate can be distinguished from each other. The smaller it is, the higher the signal to-noise 
ratios of a given climate change (Paeth et al., 2013).

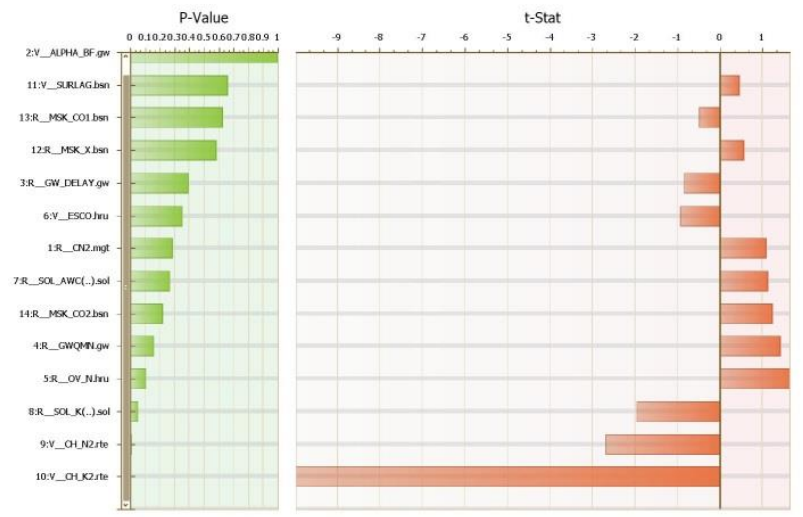

Figure 3(a). Shows the most sensitive parameters recorded after sensitivity analysis for daily calibration in SUFI- 2 .

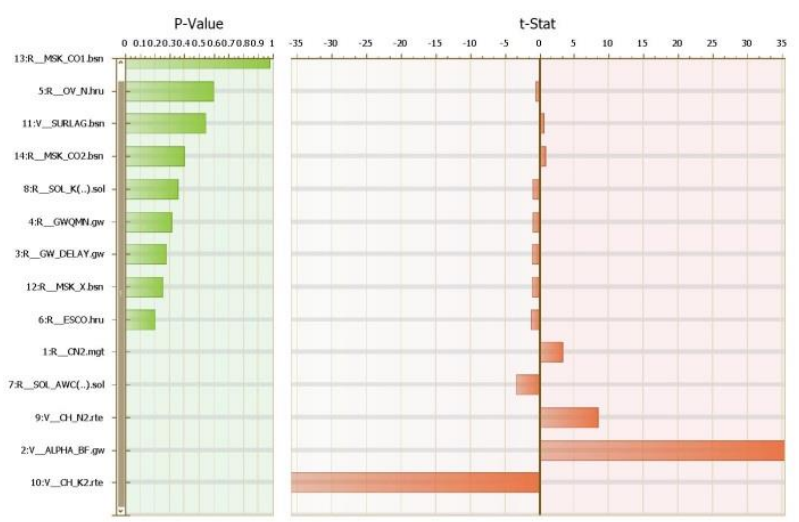

Figure 3(b). Shows the most sensitive parameters recorded after sensitivity analysis for monthly calibration in SUFI- 2 .

Similarly, the CDF tells the accumulated probability of PDF and it is also a non-decreasing (monotonic) function. In general, PDF show the probability of one specific value occurrence, whereas CDF show the probability of all values up to a certain occurrence. From the CDF, for a given probability, the corresponding streamflow value can be easily known. The value of CDF is from 0 to 1 , and the CDF provides a mapping between real values and (non-exceedance) probabilities.

The GCM model results of the present work are expressed in the probabilistic terms such as the PDF and CDF developed for the monthly streamflows of the Subarnarekha river basin in five different experimental datasets from CORDEX using RCP 4.5 and 8.5 scenarios and are shown in Figure 4. The low flow PDF calculated for 7-day and 30-day using RCP 4.5 and RCP 8.5 are given in Figure 5. It can be realized from Figures 4 and 5 that the streamflows of river basin are likely to decline in the near period (2014 - 2040). It is inferred from the results that the RCP 8.5 scenarios seem more suitable than RCP 4.5 scenarios in quantifying the uncertainties under nonstationarity assumptions.

Similarly, the forcing climate change scenarios model results of the present work are also expressed in PDF and CDF developed for monthly streamflows of the Subarnarekha river basin. This model depict the perturbed temperatures $\Delta \mathrm{T}=0$ to $4^{\circ} \mathrm{C}$ (adding the prescribed change to the baseline (0-line) simulation temperatures) and perturbed precipitations $\Delta \mathrm{P}=0, \pm 10$ to $\pm 30 \%$ (multiplied with a given factor) independently or simultaneously (Mimikou et al., 1991; Rehana and Mujumdar, 2011; Madhusudana Rao et al., 2020).

Figures 6 and 7 depict the effect of precipitation and temperature change, respectively, on monthly streamflows of Subarnarekha river basin under forcing climate change scenarios. It can be seen from Figures 6 and 7 that, monthly streamflows of Subarnarekha river basin are significantly affected due to precipitation, whereas the evapotranspiration rates are affected due to temperature variations in the study area.

The high and low flow frequency analysis in the river basin has been carried out. The high flows lead to floods, the low flows can lead to droughts. In practice, a drought refers to a period of unusually low water supplies, regardless of the water demand. The high and low flow frequency curves in the Subarnarekha river at Ghatsila gauging station are demonstrated in Figures 8 and 9 respectively, emphasizing the variations of the mean streamflows in the river basin with respect to their recurrence interval in years. The low flow duration frequency curves for recurrence interval in years considering lower return periods for uncertainty analysis are more vulnerable to climate change and most likely to alter in terms of magnitudes i.e., return level (Viessman et al., 1977).

A flow duration curve can be used to give an indication of the severity of low flows (Ponce, 1989). Such a curve, however, does not contain information on the sequence of low flows or the duration of possible droughts. The analysis is made more meaningful by abstracting the minimum flows over a period of several consecutive days. For instance, in each year, the 7-day period with minimum flow volume is abstracted, and the minimum flow is the average flow rate for that period.

In this study, the low flow duration frequency curves i.e., discharge to consecutive days of low flow in Subarnarekha river at Ghatsila gauging station for the return periods 2years, 5-years, 10-years and 30-years are shown in Figure 10. The consecutive days of low flow analysis helps in correctly assessing the drought situation in the study region in addition to the environmental flows to be maintained in the river reach. 


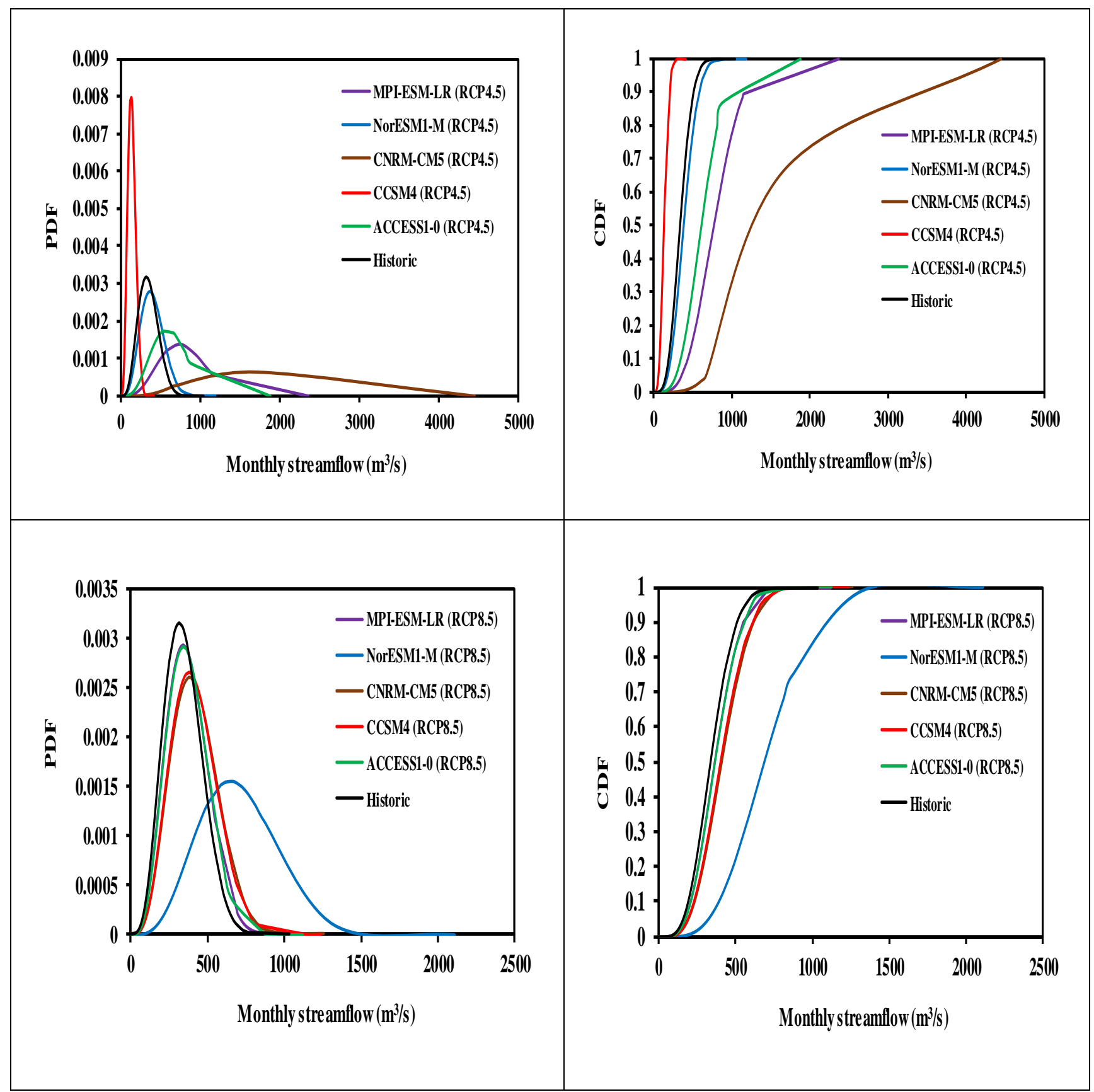

Figure 4. Show the PDF and CDF for the monthly streamflows of the Subarnarekha river basin in five different experimental datasets from CORDEX using RCP 4.5 and RCP 8.5 scenarios.

In the climate change scenarios, the risk and streamflow assessment is generally carried out through return periods under nonstationarity assumptions, as these assumptions enable to introduce the time-varying concepts for better assessment. The low flow characteristics against their recurrence periods 7-day, 30-day, and 60-day values were also estimated under nonstationarity assumptions for drought determination and aquatic ecosystems in the Subarnarekha river basin. The 7-day and 30-day nonstationarity test values for historic (1976 - 2005) period and the near (2014 to 2040) period using the RCP 4.5 and RCP 8.5 scenarios are given in Tables 4 and 5, respectively.
The nonstationarity was investigated by calculating the mean, standard deviation (SD), Coefficient of Variation (CV) and Covariance (CoV) values (Table 4 and 5) obtained for historic (1976 - 2005) period, and also for near (2014 - 2040) period under the RCP 4.5 and 8.5 scenarios. These values show the detailed quantitative descriptions of uncertainties in streamflow predictions pertaining to climate change in the study region. There was a significant nonstationarity in the spatial distribution of the CV. This value was calculated to compare both for historic and future runoff distribution in the river basin. 


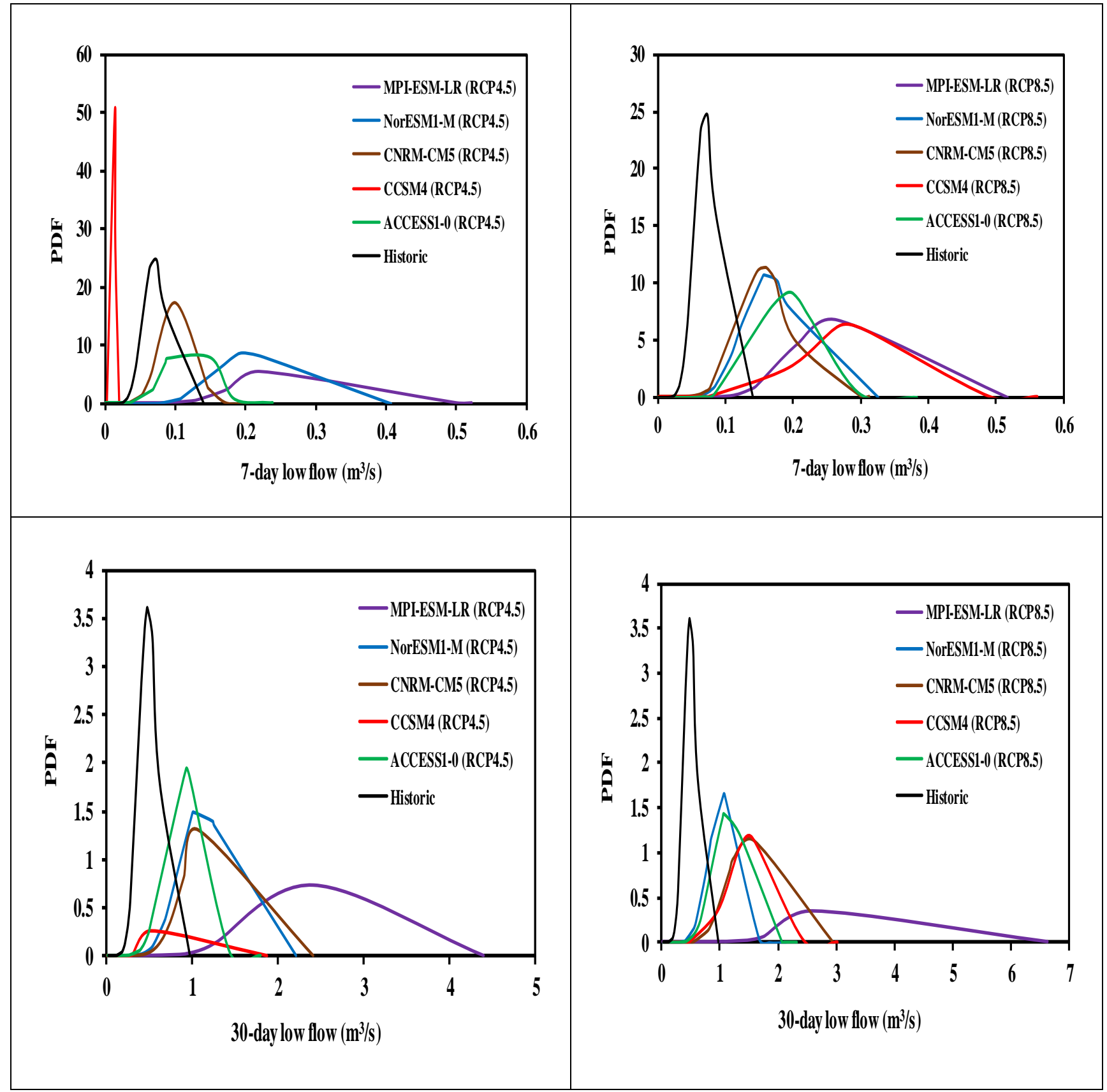

Figure 5. Low flow PDF calculated for 7-day and 30-day using RCP 4.5 and RCP 8.5 scenarios.

The ArcSWAT calibration model was used to assess the streamflows of Subarnarekha river basin along with the water balance components such as precipitation (PRECIP), surface runoff (SURQ), lateral flow (LATQ), groundwater contribution (GW_Q), percolation (PERC), soil water (SW), evapotranspiration (ET), and water yield (WYLD) on monthly time step in the study area. The calculated mean values and the percentage variations of water balance components along with streamflows for the historic total (1976 - 2013) and near (2014 - 2040) periods of Subarnarekha river basin are given in Table 6 . Here the historic total period includes the historic climate period (1976 - 2005) and the remaining past period from 2006 to 2013, i.e., till the end year for which data is available. The results from Table 6 indicate that, all the mean values of water balance components such as PRECIP (-7.93\%), SURQ (-25.17\%), LATQ (-24.81\%), GW_Q (-10.17\%), PERC (-9.28\%), SW ($5.29 \%)$ and WYLD (-19.77\%) are declining, whereas, ET $(0.62 \%)$ is increasing in the Subarnarekha river basin. The percentage variation increase (+) or decrease (-) are shown in brackets against each mean value of water balance component. Therefore, from the results it is revealed that the mean values and the percentage variation in each water balance component for future period get affected due to climate change, consequently the future streamflows $(-15.39 \%)$ are likely to decline in the river basin. 


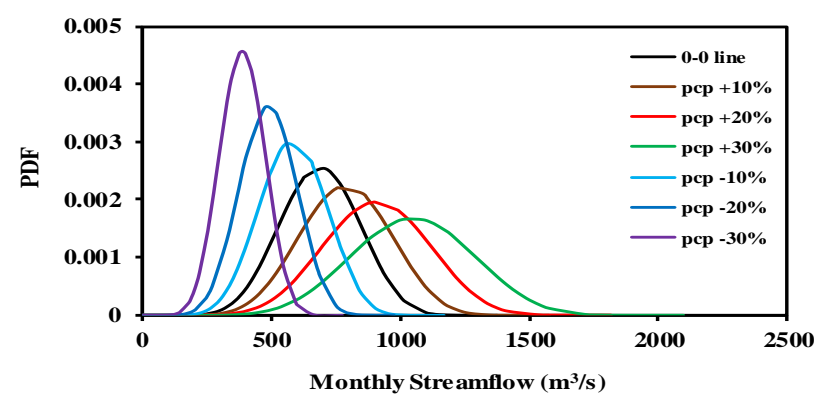

Figure 6. PDF showing the effect of precipitation change on future streamflows of Subarnarekha river basin under forcing climate change scenarios.

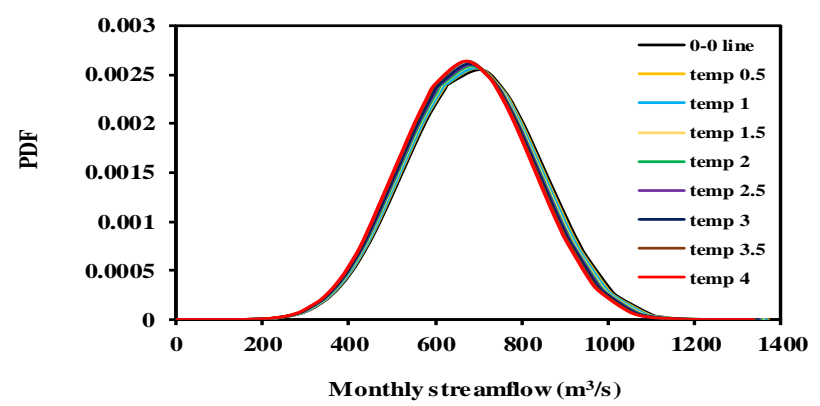

Figure 7. PDF showing the effect of temperature change on the future streamflows of Subarnarekha river basin under forcing climate change scenarios.

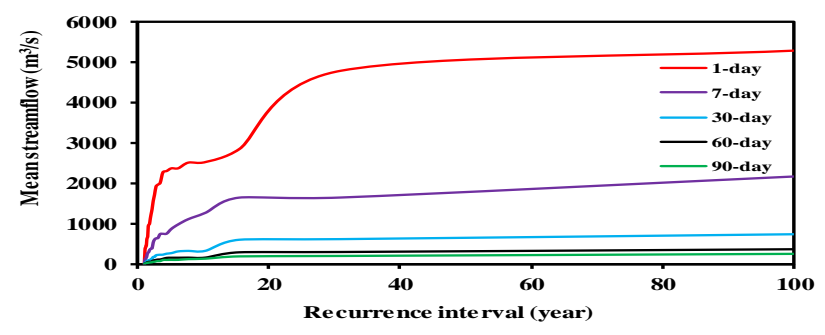

Figure 8. High flow frequency curves in the Subarnarekha river at Ghatsila gauging station.

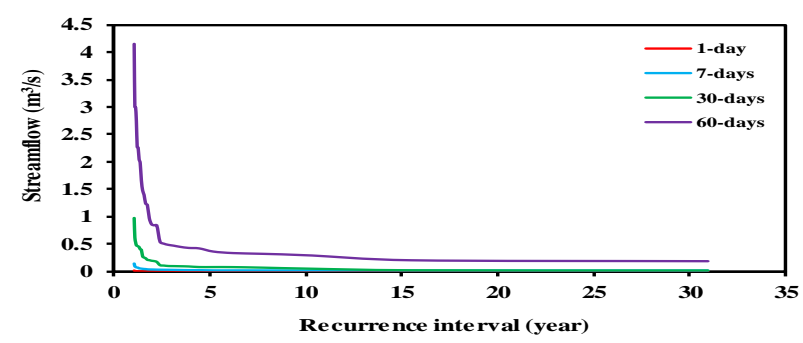

Figure 9. Low flow frequency curves in the Subarnarekha river at Ghatsila gauging station.

To conclude, from the obtained results of Subarnarekha river basin, it is important to develop certain policies for adaptation to climate change in the river basin and they need to be followed for sustainable development of water resources in the river basin.

\section{Proposed policies for adaptation to climate change in Subarnarekha river basin}

An adaptation strategy aims to increase society's resilience to climate change. According to IPCC (2007) report recommendations, a framework for managing future climate risk in the Subarnarekha river basin is suggested.

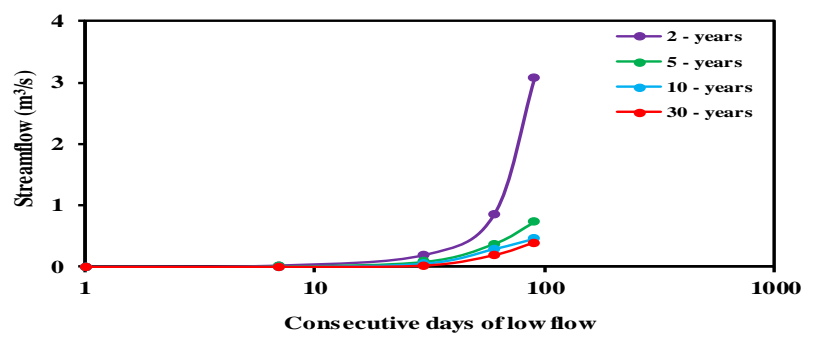

Figure 10. Low flow duration frequency curves in the Subarnarekha river basin. Discharge to consecutive days of low flow Subarnarekha river at Ghatsila gauging station.

The Subarnarekha river basin is adversely affected by the impact of climate change as it was demonstrated in the results and discussion section. Substantial percentage variation in water balance components and streamflows of river basin for future period were realized. This variation resulted in lowering of ground water and limited availability of water for agricultural and drinking purpose in summer season. Therefore, the present study highlights the broader approaches that are being proposed to facilitate adaptation to climate change as well as those that are specific to the water resources management for the study region as listed below:

- Strengthening regional governance by formulating water user association, farmer association in accord with the ministries responsible for water management in the Subarnarekha river basin.

- Providing an improved understanding and awareness of the key climate processes and the resultant climate risks and associated consequences. Some case studies on water savings and water harvesting technologies adopted in villages of study region need to be revealed.

- Promoting transbasin diversion of water in the study region, namely conveyance schemes which move water from where it is available to where water is less available, or could be employed for human development.

- Water consumption auditing and energy demands regular check in the river basin. Initiating water conservation strategies, groundwater recharging, reducing evaporation, and improved water efficiency.

- Conducting vulnerability assessments and using strategic planning to incorporate climate change into their activities. 
- Developing knowledge system to relate technology choices with time evolving climate responses.

- $\quad$ Creating an enabling environment for communitybased adaptation.

- $\quad$ Promoting public-private partnership in the policy framework.

- $\quad$ Formulating basin level adaptation strategies and action plans in developing the necessary capacities.

- Integrating climate change adaptation measures such as lake regulation, floodplains, and permanent flood protection structures in flood risk management plans by the regional water management authority.

- Comparison of community-based adaptation strategies for droughts and floods in the study region.

- Development of Integrated Water Resources Management (IWRM) to provide a useful framework to plan well-coordinated and targeted adaptation measures to climate change. IWRM is a methodical process to the sustainable development and equitable allocation of water resources through a holistic approach to water management in the study region.

\section{Conclusions}

The quantitative description of uncertainties and nonstationarity in the daily and monthly streamflows of Subarnarekha river basin for the historic (1976 - 2005) period and the near (2014 -2040) period are accurately expressed in probabilistic terms recognized as PDF and CDF for providing significant information for planning climate change adaptation policies in Subarnarekha river basin. As novelty in the work, the PDF and CDF for low flows and high flows of the river basin are developed. The analysis of nonstationary approximations of the return levels under lower and high return periods may be more beneficial to design low and high capacity hydraulic structures as per the requirement in the river basin. The future streamflows in the river basin, water balance components for historic and future periods are assessed first time for this basin.

The results revealed that the GCM and assumption of nonstationary model parameters are observed to be the main sources of uncertainty. It is realized that to cope with the uncertainties, the climate models developed based on the probabilistic approaches are very useful. The use of downscaled GCM and bias-corrected datasets as an input to the ArcSWAT hydrological model calibrated using SUFI-2 technique was successfully verified. Similar to the recent GCM models, the conventional model i.e., forcing climate change scenarios model was also verified.

The streamflows and water balance components are observed to be sensitive towards the changes in the climate and LU/LC characteristics of the river basin. The effect of model uncertainties and nonstationarity assumption on streamflow simulations was examined and an approach to obtain nonstationary hydrologic model parameters was presented. Based on the results obtained, the adaptation strategies to climate change specific to the water resources management in the study area are proposed.

In future studies of the river basin, it is suggested to conduct a vulnerability mapping of current and future climate impacts in the study area towards natural hazards. Further, without appropriate cooperation, adaptation may be limited and uneven. Therefore, research to examine the factors and processes that are important for cooperation to lead to positive adaptation outcomes and the increased adaptive capacity of water management institutions are suggested.

\section{Acknowledgements}

Authors are very much grateful to the editors and reviewers for their valuable comments which have improved the quality of the present work and the manuscript.

\section{References}

Abbaspour K.C. (2011), SWAT Calibration and Uncertainty Programs: A User Manual, SwissFederal Institute of Aquatic Science and Technology, Eawag, Dubendorf.

Abbaspour K.C., Yang J., Maximov I., Siber R., Bogner K., Mieleitner J., Zobrist J. and Srinivasan R. (2007), Modelling hydrology and water quality in the pre-alpine/alpine Thur watershed using SWAT, Journal of Hydrology, 333, pp. 413430, DOI: 10.1016_j.jhydrol.2006.09.

Arnold J.G., Srinivasan R., Muttiah R.S. and Williams J.R. (1998), Large area hydrologic modeling and assessment, Part I: Model development, Journal of the American Water Resources Association, 34, 73-89.

ASCE (1993), Criteria for evaluation of watershed models, Journal of Irrigation and Drainage Engineering, 119(3), pp. 429-442.

Banerji D. and Mukhopadhyay S. (2018), Assessment of lower Subarnarekha river's reaches through channel classification, Indian Journal of Spatial Science, 9(1), 65-73, ISSN: 22493921.

Brohan P., Kennedy J.J., Harris I., Tett S.F.B. and Jones P.D. (2006), Uncertainty estimates in regional and global observed temperature changes: A new data set from 1850, Journal of Geophysical Research, 111, D12106, DOI: 10.1029/2005JD006548.

Collins M., Booth B.B.B., Harris G.R., Murphy J.M., Sexton D.M.H. and Webb M.J. (2006), Towords quantifying uncertainty in transient climate change, Climate Dynnamics, 27, pp. 127147, DOI: 10.1007/s00382-006.

Cooley D. (2013), Return Periods and Return Levels Under Climate Change, In: AghaKouchak A., Easterling D., Hsu K., Schubert S., Sorooshian S. (eds), Extremes in a Changing Climate, Water Science and Technology Library, vol. 65, Springer, Dordrecht.

Das J. and Umamahesh N.V. (2017), Uncertainty and nonstationarity in streamflow extremes under climate change scenarios over a river basin, Journal of Hydrologic Engineering, 22(11).

Dessai S., Lu X. and Hulme M. (2005), Limited sensitivity analysis of regional climate change probabilities for the 21st century, 
Journal of Geophysical Research, 110, DOI: 10.1029/2005JD005919.

Fiseha B.M., Setegn S.G., Melesse A.M., Volpi E. and Fiori A. (2012), Hydrological analysis of the Upper Tiber River Basin, Central Italy: A watershed modelling approach, Hydrological Processes, John Wiley \& Sons, Ltd., DOI: 10.1002/hyp.9234.

Gassman P.W., Reyes M.R., Green C.H. and Arnold J.G. (2007), The Soil and Water Assessment Tool: Historical Development, Applications and Future Research Directions, Transactions of the ASABE, 50(4), pp. 1211-1250.

Gillingham K., Nordhaus W., Anthoff D., Blanford G., Bosetti V., Christensen P., McJeon H., Reilly J., and Sztorc P. (2015), Modeling Uncertainty in Climate Change: A Multi-Model Comparison, MIT Joint Program on The Science and Policy of Global Change, Report no. 290.

Giorgi F. and Mearns L.O. (2003), Probability of regional climate change based on the Reliability Ensemble Averaging (REA) method, Geophysical Research Letters, 30(12), 1629, DOI: 10.1029/2003GL017130.

Government of Jharkhand (2013), Jharkhand-Action Plan on Climate Change (JAPCC) report, Jharkhand Tribal Development Society, Ranchi, Jharkhand.

Gupta H.V., Sorooshian S. and Yapo P.O. (1999), Status of automatic calibration for hydrologic models: comparison with multilevel expert calibration, Journal of Hydrologic Engineering, 4(2), 135-143.

Hingray B., Mezghani A. and Buishand T.A. (2007), Development of probability distributions for regional climate change from uncertain global mean warming and an uncertain scaling relationship, Hydrology and Earth System Sciences (Discussions), 11(3), 1097-1114.

Huang M. and Liang Xu. (2006), On the assessment of the impact of reducing parameters and identification of parameter uncertainties for a hydrologic model with applications to ungauged basins, Journal of Hydrology, 320(1-2), 37-61, DOI: 10.1016/j.jhydrol.2005.07.010.

Hunt B.G. (2011), The role of natural climatic variation in perturbing the observed global mean temperature trend, Climate Dynamics, 36, 509-521, DOI: 10.1007/s00382-0100799-x.

IITM (Indian Institute of Tropical Meteorology) (2016), Climate data portal-CCCR. http://cccr.tropmet.res.in/home/ftp_data.jsp.

IPCC (2007), Climate change 2007 - the physical basis. Contribution of Working Group I to the Fourth Assessment Report of the IPCC. Cambridge.

IPCC (2014), Climate Change - Mitigation of Climate Change. Working Group III Contribution to the Fifth Assessment Report of the Intergovernmental Panel on Climate Change. Cambridge University Press, Cambridge, UK, 2014.

Jana S., Das M., Roy D., Das S. and Mazumdar A. (2015), Simulation of climate change impact in a river basin in Eastern India, Int. J. Hydrology Science and Technology, 5(4), 314 332.

Jana S., Dutta S., Das S. and Roy D. (2018), Uncertainty in Hydrologic response of a river Basin in india to changed climate scenario, Water \& Energy International (Water Resources Section), September 2018, pp. 68-75.

Jobst A.M., Kingston D.G., Cullen N.J., and Schmid J. (2018), Intercomparison of different uncertainty sources in hydrological climate change projections for an alpine catchment (upper Clutha River, New Zealand), Hydrology and Earth System Sciences, 22, 3125-3142, https://doi.org/10.5194/hess-22-3125-2018.

Joseph B. (2009), Environmental Studies, 2nd edition, the McGraw Hill Companies.

Kay A.L., Davies H.N., Bell V.A. and Jones R.G. (2009), Comparison of uncertainty sources for climate change impacts: flood frequency in England, Climatic Change, 92(1-2), 41-63.

Kiely G. (2007), Environmental Engineering, the McGraw Hill Companies.

Kumar N., Tischbein B., Kusche J., Laux P., Beg M.K. and Bogardi J.J. (2017), Impact of climate change on water resources of upper Kharun catchment in Chhattisgarh, India, Journal of Hydrology: Regional Studies, 13, 189-207, DOI: 10.1016/j.ejrh.2017.07.008.

Kumar P. and Joshi V. (2019), Modelling surface run-off response using hydrological model SWAT in the upper watershed of river Subarnarekha, India, Earth Sciences Malaysia, 3(2),9-15, DOI: 10.26480/esmy.02.2019.09.15.

Kure S., Jang S., Ohara N., Kavvas M.L. and Chen Z.Q. (2013), Hydrologic impact of regional climate change for the snowfed and glacierfed river basins in the Republic of Tajikistan: hydrological response of flow to climate change, Hydrological Processes, 27, 4057-4070.

Leander R. and Buishand T.A. (2007), Resampling of regional model climate output for the simulation of extreme river flows, Journal of Hydrology, 332, 487-496.

Lee J.K., Kim Y.O. and Kim Y. (2016), A new uncertainty analysis in the climate change impact assessment, International Journal of Climatology, 37(10), 3837-3846.

Mackay J.D., Barrand N.E., Hannah D.M., Krause S., Jackson C.R., Everest J., Ađalgeirsdóttir G. and Black A.R. (2019), Future evolution and uncertainty of river flow regime change in a deglaciating river basin, Hydrology and Earth System Sciences, 23, 1833-1865, DOI: 10.5194/hess-23-1833-2019.

Madhusudana Rao C., Bardhan A. and Patra J.P. (2020), Assessment of hydrological response in Subarnarekha river basin under anticipated climate change scenarios, Global NEST Journal, 22(2), 207-219, https://doi.org/10.30955/gnj.003191

Mandal S. and Simonovic S.P. (2017), Quantification of uncertainty in the assessment of future streamflow under changing climate conditions, Hydrological Processes, 31, 2076-2094, https://doi.org/10.1002/hyp.11174.

Milly P.C.D., Betancourt J., Falkenmark M., Hirsch R.M., Kundzewicz Z.W., Lettenmaier D.P. and Stouffer R.J. (2008), Stationarity is dead: Whither water management? Climate Change, policy forum, 319, www.sciencemag.org.

Mimikou M.A., Hadjisavva P.S., Kouvopoulos Y.S. and Afrateos H. (1991), Regional climate change impacts: II. Impacts on water management works, Hydrological Sciences Journal, 36(3), 259-270, https://doi.org/10.1080/02626669109492508.

Mishra V. and Lilhare R. (2016), Hydrologic sensitivity of Indian sub-continental river basins to climate change, Global and Planetary Change, DOI: 10.1016/j.gloplacha.2016.01.003.

Mohammed K., Islam A.K.M.S., Islam G.M.T., Alfieri L., Bala S.K. and Khan M.J.U. (2017), Impact of high-end climate change on floods and low flows of the Brahmaputra river, Journal of Hydrologic Engineering, 22(10), DOI: 10.1061/(ASCE)HE.19435584.0001567. 
Mondal A. and Mujumdar P. (2016), Detection of Change in Flood Return Levels under Global Warming, Journal of Hydrologic Engineering, 21(8).

Moriasi D.N., Arnold J.G., VanLiew M.W., Bingner R.L., Harmel R.D. and Veith T.L. (2007), Model evaluation guidelines for systematic quantification of accuracy in watershed simulations, Transactions of the ASABE, 50(3), pp. 885-900.

Mudbhatkal A., Raikar R.V., Venkatesh B. and Mahesha A. (2017), Impacts of climate change on varied river-flow regimes of southern India, Journal of Hydrologic Engineering, 22(9), DOI: 10.1061/(ASCE)HE.1943-5584.0001556.

Mujumdar P.P. and Ghosh S. (2008), Modeling GCM and scenario uncertainty using a possibilistic approach: Application to the Mahanadi River, India. Water Resources Research. 44, W06407, DOI: 10.1029/2007WR006137.

Narsimlu B., Gosain A.K. and Chahar B.R. (2013), Assessment of Future Climate Change Impacts on Water Resources of Upper Sind River Basin, India Using SWAT Model, Water Resource Management, 27, 3647-3662, DOI: 10.1007/s11269-0130371-7.

Narsimlu B., Gosain A.K., Chahar B.R., Singh S.K. and Srivastava P.K. (2015), SWAT Model Calibration and Uncertainty Analysis for Streamflow Prediction in the Kunwari River Basin, India, Using Sequential Uncertainty Fitting, Environmental Processes, 2, 79-95, DOI: 10.1007/s40710-015-0064-8.

Nash J.E. and Sutcliffe J.V. (1970), River flow forecasting through conceptual models: Part I. A discussion of principles, Journal of Hydrology, 10(3), 282-290.

Paeth H., Hall N.M., Gaertner M.A., Dominguez M.A.S., Moumouni S., Polcher J., Run P.M., Fink A.H., Gösset M., Lebel T., Gaye A.T., Rowell D.P., Moufou W.M., Jacob D., Rockel B., Giorgi F. and Rum M.M. (2010), Progress in regional downscaling of West African precipitation, Atmospheric Science Letters, 12, 75-82, DOI: 10.1002/asl.306.

Paeth H., Steger C. and Merkenschlager C. (2013), Climate change - It's all about probability, Erdkunde, 67(3), 203-222.

Palmer T.N. and Anderson D.L.T. (1994), The prospects for seasonal forecasting - A review paper, Quarterly Journal of the Royal Meteorological Society, 120, 755-793.

Ponce V.M. (1989), Engineering Hydrology, Prentice Hall, Inc. New Jersey. ISBN 0-13-277831-9.

Prudhomme C. and Davies H. (2009a), Assessing uncertainties in climate change impact analyses on the river flow regimes in the UK. Part 1: baseline climate, Climatic Change, 93, 177195, DOI: 10.1007/s10584-008-9464-3.

Prudhomme C. and Davies H. (2009b), Assessing uncertainties in climate change impact analyses on the river flow regimes in the UK. Part 2: future climate, Climatic Change, 93, 197-222.

Rai P., Choudhary A. and Dimri A.P. (2019), Future precipitation extremes over India from the CORDEX-South Asia experiments, Theoretical and Applied Climatology, DOI: 10.1007/s00704-019-02784-1.

Ramadan H.H., Beighley R.E. and Ramamurthy A.S. (2013), Sensitivity analysis of climate change impact on the hydrology of the Litani Basin in Lebanon, International Journal of Environment and Pollution, 52(1/2), 65-81, DOI: 10.1504/IJEP.2013.056359.

Read L.K. and Vogel R.M. (2015), Reliability, return periods, and risk under nonstationarity, Water Resources Research, 51, 6381-6398, DOI: 10.1002/2015WR017089.
Rehana S., Mujumdar P.P. (2011), River water quality response under hypothetical climate change scenarios in TungaBhadrariver, India, Hydrological Processes, 25, 3373-3386, DOI: 10.1002/hyp.8057.

Shabalova M.V., Van Deursen W.P.A. and Buishand T.A. (2003), Assessing future discharge of the river Rhine using regional climate model integrations and a hydrological model, Climate Research, 23, 233-246.

Shawul A.A., Alamirew T. and Dinka M.O. (2013), Calibration and validation of SWAT model and estimation of water balance components of Shaya mountainous watershed, Southeastern Ethiopia, Hydrology and Earth System Sciencess Discussions, 10, 13955-13978, www.hydrol-earth-syst-scidiscuss.net/10/13955/2013/doi:10.5194/hessd-10-139552013.

Singh J., Knapp H.V. and Demissie M. (2004), Hydrologic modeling of the Iroquois River watershed using HSPF and SWAT. ISWS CR 2004-08. Champaign, III.: Illinois State Water Survey.

Spafford L. and MacDougall A.H. (2020), Quantifying the probability distribution function of the transient climate response to cumulative $\mathrm{CO}_{2}$ emissions, Environmental Research Letters, 15, DOI: 10.1088/1748-9326/ab6d7b.

Sung J.H., Eum H., Park J. and Cho J. (2018), Assessment of Climate Change Impacts on Extreme Precipitation Events: Applications of CMIP5 Climate Projections Statistically Downscaled over South Korea, Advances in Meteorology (Hindawi), 2018, 4720523, 4720523.

https://doi.org/10.1155/2018/

Uniyal B., Jha M.K. and Verma A.K. (2015), Parameter Identification and Uncertainty Analysis for Simulating Streamflow in a River Basin of Eastern India, Water Resources Research, DOI: 10.1002/hyp.10446.

Vanem E. (2015), Uncertainties in extreme value modelling of wave data in a climate change perspective, J. Ocean Eng. Mar. Energy, 1, 339-359, DOI: 10.1007/s40722-015-0025-3.

Verma A.K. and Jha M.K. (2015), Evaluation of a GIS-Based Watershed Model for Streamflow and Sediment-Yield Simulation in the Upper Baitarani River Basin of Eastern India, Journal of Hydrologic Engineering, 20(6), DOI: 10.1061/(ASCE)HE.1943-5584.0001134.

VIC Model User Guide, https://vic.readthedocs.io/en/master/ Documentation/UserGuide/

Viessman Jr., Knapp J.W. and Harbaugh T.E. (1977), Introduction to Hydrology, Harper \& Row, Publishers, New York. ISBN 07002-2497-1.

Wilby R.L. and Harris I. (2006), A framework for assessing uncertainties in climate change impacts: Low-flow scenarios for the River Thames, UK, Water Resources Research, 42, W02419, DOI: 10.1029/2005WR004065.

Wilks D.S. (2006), Statistical Methods in the Atmospheric Sciences, Amsterdam.

Xu L., Xie Z. and Huang M. (2003), A new parameterization for surface and groundwater interactions and its impact on water budgets with the variable infiltration capacity (VIC) land surface model, Journal of Geophysical Research, 108(D16), DOI: 10.1029/2002JD003090.

Yaduvanshi A., Sharma R.K., Kar S.C. and Sinha A.K. (2017), Rainfall-runoff simulations of extreme monsoon rainfall events in a tropical river basin of India, Natural Hazards, DOI: 10.1007/s11069-017-3075-0. 
Yaduvanshi A., Sinha A.K. and Haldar K. (2019), A century scale hydro-climatic variability and associated risk in Subarnarekha river basin of India, Modeling Earth Systems and Environment, DOI: 10.1007/s40808-019-00580-4.

Yapo P.O., Gupta H.V. and Sorooshian S. (1996), Automatic Calibration of Conceptual Rainfall-Runoff Models: Sensitivity to Calibration Data, Journal of Hydrology, 181(1-4), 23-48. 